\title{
MODERN APPROACHES TO TRAINING OF PEDAGOGICAL SPECIALISTS OF MUSICAL ARTS
}

\author{
Valentyna Vodiana ${ }^{1}$, Larysa Oronovska ${ }^{2}$, Anatoliy Oronovskyy ${ }^{3}$ \\ ${ }^{I}$ Ph.D. (Pedagogy), Associate Professor, Department of Musicolog and Methodology of Musical Art, Faculty \\ of Arts, Ternopil Volodymyr Hnatiuk National Pedagogical University, Ternopil, Ukraine, e-mail: \\ vvodyana@gmail.com,ORCID: https://orcid.org/0000-0001-6358-1680 \\ ${ }^{2}$ Ph.D. (Pedagogy), Associate Professor, Department of Musicology and Methodology of Musical Art, \\ Faculty of Arts, Ternopil Volodymyr Hnatiuk National Pedagogical University, Ternopil, Ukraine, e-mail: \\ lorikulya@gmail.com,ORCID: https://orcid.org/000-0002-2701-1290 \\ ${ }^{3}$ Assistant, Department of Musicology and Methodologo of Musical Art, Faculty of Arts, Ternopil Volodymyr \\ Hnatiuk National Pedagogical University, Ternopil, Ukraine, e-mail: oronovsky22@gmail.com, ORCID: \\ https://orcid.org/0000-0002-8912-6763
}

Abstract. The content of approaches to the professional training of teachers of music arts is determined by a number of objective factors due to the realities of modern life. They pose challenges to standardized education systems, stimulating the study and implementation of foreign educational traditions and innovative practices in the domestic space that would adapt the system of national higher education to adequate functioning on a global scale. The purpose of the present investigation is to study modern domestic and global approaches to training of pedagogical specialists in music arts as part of the intensification of globalization processes. As a result, these approaches will stimulate the integration of educational space, and ensure increased dynamics of using information and media teaching tools. Methods of observation, description, complex analysis, functional method, method of comparison, method of system analysis, method of generalization and method of scientific abstraction have been used. The defining feature of modern approaches to training of pedagogical specialists in music arts is the tendency to globalization and integration of educational space. This will further determine the expanded involvement of distance learning methods, informatization of educational space, attitude to lifelong learning and, in general, a conscious and self-motivated attitude towards the process of acquiring knowledge and obtaining the necessary professional skills. Globalization processes of a music teacher in the education intensify the weight of art education and training of a pedagogical specialist of musical arts as a carrier and conductor of world cultural values. However, against this background, we should not forget about music as a source of national education of the younger generations. Therefore, a balance between national and globalization dominants is needed in the methodology of teaching music disciplines in the course of university training of music teachers.

Keywords: music teachers (pedagogical specialist of musical arts), integration, globalization, informatization of education, unified educational space, distance learning, preservation of national and cultural identity.

JEL Classification: H52, H75, I23, I25.

Formulas: 0; fig.: 0; tabl.: 0; bibl.: 17

Introduction. Characteristic features of modern education are global informatization and integration. They lead to the emergence of the concept of "unified, or common, educational space" in the world. This applies to absolutely all parts of the educational process; however, currently it is especially noticeable in the field of higher education, which may be connected with a global multifaceted policy of integration between countries, especially those that have partnerships and are jointly members of international organizations. For instance, when taking into account the factors of strengthening integration in Ukraine, it is expedient to highlight the updated requirements for HEI (higher educational institutions) that have the status 
of national or apply for its acquisition. The relevant resolution of the Cabinet of Ministers regulates the average annual number of foreign citizens and citizens of member states of the Organization for Economic Cooperation and Development among applicants for higher education in the institutions of higher education (Cabinet of Ministers of Ukraine, 2017). The integration process is also stimulated by the requirements for research and teaching staff regarding the number of publications in the world scientometric databases Scopus or Web of Science. All this and other factors, conditioned by the realities of modern life, pose new challenges to education systems and stimulate the study and implementation of foreign educational traditions and innovative practices in the domestic space that would adapt the system of domestic higher education to adequate functioning on a global scale. In addition, the COVID-19 pandemic made it necessary to fundamentally revise the approaches to the educational process in the direction of the development of digitalization, which first of all requires updating the material and technical bases of the HEI, the development of combined educational programs (curricula) with the possibilities of intensive use of distance education, as well as work in the direction of stimulating the motivation of students towards educational and scientific (especially at the master's level) activities. The context of music education in the paradigm of actualized factors, determining the content of modern approaches to training of teachers at the bachelor's and master's level, requires a special narrow-sectoral approach to outlining this topic. All this constitutes the relevance of this topic and, on the other hand, determines the directions of its representation in the presented intelligence.

Literature Review. In the literature review, we will try to find out the basic world directions of scientific research on innovations in the course of training pedagogical specialists of musical arts with an emphasis on the reforms caused by modern globalization processes and related processes of digitalization of the educational process. Poblete et al. (2019) focuses on the need for pre-university training of applicants for the profession of a music teacher and the implementation of the principles of multilevel education of a pedagogical specialist of musical arts, when his artistic component develops from an early age. Timonen et al. (2020) concentrates on the challenges facing teachers - music researchers in the context of intercultural communication. The publication "The Oxford handbook of preservice music teacher education in the United States", edited by Conway et al., is complex and multi-vector (2019). A wide range of topical issues has been covered in this publication: from the history of music pedagogy in the United States to attempts at philosophical understanding of changes in the training of music teachers.

The article by Palkki \& Sauerland (2019) on young music teachers declaring their non-traditional orientation and transgenderism is one among the most innovative directions of scientific research. Researchers consider this subject matter relevant because, according to their viewpoint, modern students of music educational institutions and educators of music pedagogical universities often openly declare their support for LGBTQA communities. Palkki \& Sauerland (2019) provide a systematic list of tokens that can be useful when covering gender issues in the professional university training of music teachers. They describe relevant methods of interaction 
and even suggest lesson plans and pedagogical projects that can be used in the professional training of pedagogical specialists of musical arts with regard to gender issues. It should be noted that for the post-Soviet pedagogical space, this vector is still quite provocative. However, taking into account the realities of the Western world, this direction of scientific and pedagogical attention is becoming more common. Along with current dominant globalization processes, it should be expected that problems of this nature may soon become relevant for domestic music pedagogy of higher educational establishment.

The article by Montgomery et al., (2019) is devoted to the use of educational analytics in order to understand the nature and mechanisms of self-education in the system of mixed (combined) model of training music teachers. Data on self-education of future music teachers in the process of students' interaction with course materials on the Moodle educational platform within the framework of blended learning as a popular model of online learning in the field of higher education in the world practice have been taken for assessment. According to the empirical data obtained, the basic indicators of the self-education performance level of pedagogical specialists of musical arts were the indicators of daily use of the Moodle educational platform and indicators of the frequency of access to the system: the more often and regularly students entered their accounts, the better were the results of their implementation of self-study programs.

Wang (2019), who considers the professional training of a music teacher in the context of integration processes in the field of education, is important for our chosen vector of the research on the problem of university training. In particular, the author highlights the functions of professional training of music teachers, implemented in the context of international integration. He also describes the structure of professional training of music teachers in terms of international integration, as well as identifies the developmental potential of integration processes in education and its impact on the formation of relevant qualities of pedagogical specialists of musical arts.

By the way, the works of Bohdanyuk (2020), Havrilova (2017), Umrykhina deserve careful attention from the circle of domestic researchers of the specifics of music education in the paradigm of globalization and integration processes. The works of Funerova et al. (2019), Zamorotskaya (2019), Prokopchuk (2020) are very important in the paradigm of the widespread use of distance education in the training of pedagogical specialists of musical arts.

Although the professional training of applicants for bachelor's and master's degrees in musical pedagogical specialties is the subject of constant attention of researchers, the topic still requires fundamental study in the direction of highlighting the priority modern approaches to the professional training of music teachers.

Aims. Therefore, the purpose of the present investigation is to study modern domestic and global approaches to training of pedagogical specialists of musical arts within the intensification of globalization processes, which stimulates the integration of educational space, and increased dynamics of information and media teaching tools. 
Methods.The outlined purpose requires the involvement of a wide range of scientific methods. In particular, in the process of preparation of this scientific research, the methods of observation, description, complex analysis, functional method, method of comparison, method of system analysis, method of generalization and method of scientific abstraction have been used. Along with this, modern standards of higher education in Ukraine for training of applicants for music and pedagogical specialties of Ukraine, as well as the legal framework in the sphere of education towards promoting the integration of educational space have been studied.

Results. The professional training of a music teacher is a certain hierarchical structure of the student's professional "I". It involves the integration of a complex range of competences into this personal structure, the full implementation of which means the formation of specific professional qualities and personality traits. This is an interactive process of dynamic, conscious, purposeful and socially determined (because at the stage of professional self-determination, social implementation of the personality takes place) personality transformation in the process of professional musical and pedagogical training. It is focused on the formation of personal and professionally significant qualities and competences of a specialist. This process is at least two-tiered, two directional, namely: on the one hand, there is a formation of competences of the expert in a certain kind of musical art (with setting "I know by myself"), on the other hand - competences of the professional teacher).

Training of pedagogical specialists of musical arts, as regulated by the relevant resolutions of the Cabinet of Ministers of Ukraine, is carried out within two fields of knowledge:

1) pedagogical training of music specialists with the opportunity to work at secondary schools, gymnasiums, lyceums, colleges, establishments of extracurricular education system, where specialists in the field of music are needed (clubs, children's art centers, etc.) - in the field of knowledge 01 "Education" in the specialty 014 "Secondary education (by subject specializations)", where the subject specialty 014.13 "Secondary education (Music)" prepares teachers of music.

2) professional training in the field of 02 "Culture and Art" in the specialty 025 "Musical Arts" (Cabinet of Ministers of Ukraine, 2015). As of 2020, 52 higher educational institutions of Ukraine train specialists in this subject specialty. The graduate may also additionally need pedagogical qualification within the framework of postgraduate education for his pedagogical activity.

Training of pedagogical specialists of musical arts involves mastering certain cycles of disciplines, namely: 1) musical and theoretical;2) musical and historical; 3) musical and instrumental; 4) conductor and choir; 5) disciplines related to mastering the method of music education (methods of pedagogical musical activity). Herewith, paragraph 5 similarly, but to a different extent, relates to the structure of both of these areas of musical training. This is justified by the fact that the standard for the specialty 025 "Musical Art" enshrines the acquisition of the appropriate educational qualification level (for instance, Bachelor of Music) and diversified specialization of the relevant educational program (curriculum). This diversified specialization means that training can be carried out in two main areas of qualification, namely: 1) 
performance / composition / conducting / musicological qualification; 2) teaching qualifications, within the framework of which there is an increased emphasis on modern methods of teaching musical art in the educational and professional programs of universities (to fulfill the professional duties of an instrumentalist teacher, teacher of a vocational educational institution, teacher of choral disciplines).

The content of professional training of applicants in selected specialties is regulated by higher education standards. For instance, for the specialty 025 "Musical Art", this standard was approved in 2019 (both for bachelor's and master's levels); then for the subject specialty 014.13 "Secondary education (Music Art)", the directive is still a temporary standard, taken by the Ministry of Education and Science of Ukraine as a basis in 2016.

With regard to globalization processes in the field of music education, the compliance of the Bologna Process with the international project of the European Commission "Harmonization of educational structures in Europe" (Tuning Educational Structures in Europe) is fundamental for the standards of higher education in music. It is necessary to pay attention to tendencies concerning regulation of requirements to scientific activity by experts in the field of music. As it is known, focusing on the world standards of higher education, graduates of universities, applying for diplomas with honors, are required not only to master the content of academic disciplines at a high level, but also to carry out scientific activities, the achievements of which should be reflected in the relevant scientific publications. Enhanced requirements for the scientific activity of the teaching staff of Ukrainian universities are also dictated by adaptation to international standards. However, adjustments have been made for teachers of art specialties at the regulatory level. Thus, they do not have to get a degree if they have special honors for their own artistic musical activity. For instance, the standard requirements for national HEIs regulate that cultural and art workers, working in an institution of higher education at their main place of work, are equated to scientific and pedagogical workers with a scientific degree if they are awarded the honorary titles "People's Artist of Ukraine", "Honored Worker of Arts of Ukraine", "Honored Artist of Ukraine". Such approach is fully consistent with the nature of activity in the paradigm of music. It emphasizes the dominance of artistic talent, which is a unique personal heritage; consequently, it can be equated in academic weight to the achievements of scientific creativity.

Modern globalization approaches to training of musicians-teachers also dictate increased attention to the mastery of foreign languages by students, in particular, special terminology in foreign language interpretation. This allows carriers of educational and qualification levels in the field of musical art carrying out an interethnic scientific and cultural dialogue at an optimal level. In addition, it helps adapt more quickly to foreign standards of teaching and learning in case of employment abroad.

Regarding the digitalization of the educational process, this area is also enshrined in the standards of the outlined specialties. Thus, it has been indicated that the instruments and equipment for mastering the subject area are not only a range of musical instruments, but also computer software, multimedia tools in the field of 
music. In addition, in general competences, we find the requirement for the ability of an applicant for higher music education to search, process and analyze information from various sources, to acquire skills in using information and communication technologies, skills in the application of alternative innovative technologies for musicology, performing, composing, conducting, teaching. The clarification for the temporary standard of the subject specialty 014.13 "Secondary education (Music Art)" is the ability of the applicant to use modern information pedagogical technologies in order to ensure the quality of the educational process at secondary educational institutions, institutions of extracurricular art education.

Informatization of the educational space expands the variability, plasticity of the educational process; it designates its adaptability to the realities of life. Thus, the consolidation of these competences in the standards provides further legitimacy of distance learning under the conditions of COVID-19 pandemic; it regulates the ability of applicants in the field of music to study by applying multimedia tools. In addition, informatization is one of the determining factors in the implementation of world standards of lifelong learning: the graduate must be able to learn throughout life and improve qualifications, acquired during training, with a high level of autonomy (Ministerstvo osvity i nauky Ukrayiny, 2017).

In the paradigm of the realities of life in 2020, distance learning in an innovative form of implementation of the educational process has become temporarily normative. In the future, it should be expected that distance learning tools in the preparation of bachelors and masters, in particular, teachers of musical arts, will remain in leading positions among the forms of higher education. However, the artistic and practical nature of the specialties that are the subject of this study, complicate the interaction of the subjects of the educational process in higher educational institutions in terms of distance learning.

Thus, the defining feature of modern approaches to pedagogical training of pedagogical specialists in music can be called the tendency to globalization and integration of educational space. It will further determine the expanded involvement of distance learning methods, informatization of educational space, attitude to lifelong learning and, in general, a conscious and self-motivated attitude to the process of acquiring knowledge and obtaining the necessary professional skills.

Discussion. The Strategy of Ukraine's integration into European Union was approved by the relevant decrees of the President of Ukraine. According to them, the basic directions of cultural, educational and scientific and technical integration have been determined through the introduction of European norms and standards in the domestic educational system, on the one hand, and on the other - the dissemination of domestic cultural and scientific and technical achievements within European Union and on the scale of the world community. This is a guarantee of mutual cultural and educational benefits from integration; it contributes to the enhancement of European cultural identity in Ukraine. In addition, it also enriches the European cultural identity with Ukrainian national musical achievements. Integration is a tool of educational and artistic entry of Ukraine into the European intellectual-educational and scientifictechnical space (Umrykhina, 2019). 
Thus, currently the priority of higher education development in the global context is the globalization (internationalization) of the educational environment, which means the involvement of domestic educational institutions in the global educational space in the framework of the formation of "unified educational environment" concept. Globalization highlights the need to train pedagogical specialists in the direction of musical arts in line with the ability to intercultural interaction in a global multinational multicultural society (Prokopchuk, 2020). Globalization processes in the education of musician-teacher intensify the importance of art education and training of music teachers as a carrier and introducer of world cultural values. However, against this background, we should not forget about music as a source of national education of the younger generations. Therefore, a balance between national and globalization dominants is needed in the methodology of teaching music disciplines in the course of university training of musicians-teachers.

In modern conditions, an approach is being formed to the interpretation of artistic competence as a synonym for the professional competence of a teacher of artistic disciplines, in particular musical arts (Havrilova, 2017). Without one's own creative potential and a conscious attitude to its development and enrichment on the part of the applicant for the profession of music teacher, it is difficult to imagine a full-fledged professional personality of a music teacher. In the paradigm of modernity, this approach remains at the forefront. The professional activity of music teachers (both creative and directly practical and methodical) plays a significant role in involving the younger generation in the national and world art space. Therefore, the profession of music teacher is designed to break the stereotypes of pupils in relation to the musical arts (Bohdanyuk, 2020). Therefore, the modernized process of professional training of the future musician-teacher contains a wide range of requirements for professional mobility, managerial qualities, readiness to organize cultural and permissive activities of schoolchildren, pupils of music schools, specialized circles, etc., as well as the entire teaching staff. The modern approach to this semantic line again requires a balance between the world musical heritage, national music, modern trends in the musical arts at the level of national development and in the paradigm of the world dimension. This perspective is relevant to the assessment of the readiness of future music teachers to take responsibility for the spiritual and artistic development of their pupils, which is usually assessed as insufficient at the graduate level. The source of development of spiritual and creative potential of pupils of music schools, clubs and general and specialized establishments of secondary, primary and preschool education can be considered, for example, educational potential of Ukrainian musical art, which at the mental-genetic level affects the personality of both the future music teacher and his pupils (Bohdanyuk, 2020). Toward this end, it is possible to accompany classes for Ukrainian pedagogical musical practice not only traditionally on the piano, but also with the use of national musical instruments, namely: bandura, flute, etc. - depending on the skills and capabilities of the teacher, his preferences and directly depending on the educational musical material. Through the implementation of the national component in line with globalization processes, digitalization, which erase the national 
framework of musical life, the chance arises not to lose national self-identity in music, but, on the contrary, enrich and promote it, adapting to modern trends in music. Consequently, this will enrich the world heritage, while ensuring the preservation of cultural traditions in the musical sound and approaches to the teaching activities of music professionals.

On the other hand, high-quality professional training of a modern music teacher cannot be considered complete without teaching methods of working with the latest technical means related to the music field. This is dictated by the requirements of the time and the characteristic behavioral traits of modern schoolchildren, for whom music is a means of self-expression and self-affirmation. Thereby, many students learn a computer music editor or program for creating music or rhythms in early adolescence (Bohdanyuk, 2020). Therefore, the future teacher should also be aware of this kind of programs and mobile applications, directing the individual creative searches of schoolchildren. Mastering the range of electronic music programs will also give the opportunity to improve the school repertoire, creating covers, creatively interpret musical works (in particular, in the popular direction of adaptation to the modern sound of folk song heritage), arrange musical works for certain instrumental and vocal ensembles. In addition, the basics of activities acquired during university training with electronic means of interaction with musical works and means of online interpersonal communication in order to carry out educational activities will allow the future music teacher creatively and interestingly implementing the content of the training lines in case of force majeure situations, in particular, in terms of quarantine (Funerova et al., 2019). Teaching students of pedagogical and musical specialties the ability to follow the trends of software development in the field of music will not only give impetus to the implementation of the concept of lifelong learning, but it will also contribute to the ability of the applicant to effectively stimulate the motivational aspect of pupils. One of the most effective ways of qualitative renewal of music education lies in attracting information and communication and computer technologies in music teaching (Havrilova, 2017). The role of information and multimedia literacy of a musician-teacher is insomuch great that even it is sometimes difficult to imagine the content of professional (namely information and communication) competence of a future music teacher without it (Havrilova, 2017).

An integrative approach to training of music teachers is a synthesis of professionally significant activities (pedagogical, musicological, psychological, performing, choir, vocal, concertmaster, educational, etc.) (Kozlov, 2006). Under the conditions of international integration, the professional training of a music teacher performs educational, training, integrative-coordinating, organizational-managerial, communicative, commercial functions. The structure of professional training of pedagogical specialists in musical art contains legislative, structural, normative, functional, psychological, social-cultural, educational components. The complex of professional training implements developmental potential of integration processes in education, that is, contributes to the formation of qualities of a music teacher, professionally needed in terms of global integration and the processes of digitalization. This will make it possible to prepare the expert and the professional 
who corresponds to the world educational standards, modern tendencies of development of music and pedagogical education in the world, who is capable to compete in the world music and educational space. An integrative approach to the professional education of music teachers contributes to the convergence, coherence, coordination and synchronicity of training systems of specialists in different countries, taking into account national specifics, but with a focus on the adaptability of acquired competences to the conditions of music education in the world. All this together contributes to the accumulation of experience of intercultural and interethnic communication in the subjects of the music education process. The relative coherence of vocational training systems around the world contributes to the openness of national educational systems for the implementation of international music and educational projects, educational and artistic programs, as well as for joint research, teaching and cultural activities. Such approach involves the use of resources in order to ensure the academic mobility of pupils and professional mobility of pedagogical practitioners in music (Wang, 2019).

Conclusion. Therefore, modern approaches to training of pedagogical specialists in musical arts are marked by multi-vector and variability of semantic competence lines. The leading factor in updating the content of training future music teachers is the globalization of the educational environment. Further, the decisive factors are the informatization of the music teacher's education, distance forms of educational and training interaction. The effectiveness of modern professional training of music teachers is especially influenced by their conscious attitude to their own education with the prospect of learning (self-development, professional and personal self-affirmation) throughout life. In the mainstream of globalization, a significant role is also played by approaches not only to updating the methods of teaching music, but also to developing ways to preserve national-cultural self-identity in musical creativity and the ability to position it in the European and global arena.

In general, integration processes in the education of a music teacher:

- provide wide access to global information, intellectual and educational resources;

- provide opportunities for the export and import of educational services in the field of music;

- expand the range of choice of individual strategies and trajectories of professional formation and further development;

- provide adaptability and continuity of professional training of a music teacher;

- create favorable conditions for academic mobility of pupils and professional mobility of music teachers-practitioners, as well as scientists from different countries; - provide conditions for the implementation of joint music and educational projects and programs, activities of research, teaching and cultural and educational content;

- contribute to the establishment of international educational institutions or their separate structural units;

- stimulate the development and implementation of integrated curricula, programs, universalization of educational standards.

Author contributions. The authors contributed equally.

Disclosure statement. The authors do not have any conflict of interest. 


\section{References:}

1. Bohdanyuk, V. (2020). Osoblyvosti profesiynoyi pidhotovky suchasnoho vchytelya muzychnoho mystetstva [Features of Professional Training of the Modern Teacher of Music Art]. Problemy pidhotovky suchasnoho vchytelya, 21, 21-29.

2. Conway, C., Pellegrino, K., Stanley, A. M., \& West, C. (Eds.). (2019). The Oxford handbook of preservice music teacher education in the United States. Oxford: Oxford University Press.

3. Funerova, H. Yu., Fomin, V. V., Funerova, A. Yu., \& Fomyn, V. V. (2019). Interaktyvni metody dystantsiynoho navchannya $\mathrm{u}$ fakhoviy pidhotovtsi maybutn'oho vchytelya muzychnoho mystetstva [Interactive Methods of Distance Learning in the Professional Training of Future Music Teachers]. Chas mystets'koyi osvity. Teoriya i metodyka vykhovannya khudozhn'o-obdarovanoyi osobystosti u zakladakh mystets'koyi osvity : zb. st. VII Vseukr. nauk.-prakt. konf., 17-18 zhovt. 2019 r. Kharkiv : KhNPU, 2019. Ch. 2, pp. 140-143.

4. Havrilova, L. H. (2017). Profesiyna kompetentnist' maybutnikh uchyteliv muzyky yak pedahohichnyy fenomen [Professional competence of future music teachers as a pedagogical phenomenon]. Dukhovnist osobystosti: metodolohiya, teoriya i praktyka, 2, 71-82.

5. Kabinet Ministriv Ukrayiny. (2015). Postanova vid 29 kvitnya 2015 r. no 266 «Pro zatverdzhennya pereliku haluzey znan' i spetsial'nostey, za yakymy zdiysnyuyet'sya pidhotovka zdobuvachiv vyshchoyi osvity» [Resolution of April 29, 2015 № 266 "On approval of the list of fields of knowledge and specialties in which the training of applicants for higher education"]. http://vnz.org.ua/zakonodavstvo/101-perelik-galuzej-znan-ispetsialnostej

6. Kabinet Ministriv Ukrayiny. (2017). Postanova vid 22 lystopada 2017 r. no 912 «Pro zatverdzhennya Poryadku ta kryteriyiv nadannya zakladu vyshchoyi osvity statusu natsional'noho, pidtverdzhennya chy pozbavlennya ts'oho statusu» [Resolution of November 22, 2017 № 912 "On approval of the Procedure and criteria for granting a higher education institution national status, confirmation or deprivation of this status"]. https://zakon.rada.gov.ua/laws/show/912-2017-\%D0\%BF\#Text

7. Kozlov, N. I. (2006). Teoreticheskaya $i$ metodicheskaya professional'naya podgotovka studentov pedagogicheskih vuzov $k$ formirovaniyu muzykal'nosti uchashchihsya: avtoref. dis. ... d-ra ped. nauk : 13.00.02. Moskva: Mosk. gos. otkrytyj ped. un-t im. M. A. Sholohova.

8. Ministerstvo osvity i nauky Ukrayiny. (2017). Tymchasovyy standart vyshchoyi osvity Ukrayiny spetsial'nosti 014.13 «Serednya osvita (Muzychne mystetstvo)» [Temporary standard of higher education of Ukraine, specialty 014.13 "Secondary education (Music)"]. https://cutt.ly/vhWPnJ2

9. Ministerstvo osvity i nauky Ukrayiny. (2019). Nakaz vid 24.05.2019 no. 727 «Pro zatverdzhennya standartu vyshchoyi osvity za spetsial'nistyu 025 «Muzychne mystetstvo» dlya pershoho (bakalavrs'koho) rivnya osvity» [Order of 24.05.2019 №727 "On approval of the standard of higher education in the specialty 025" Music "for the first (bachelor's) level of education"]. https://mon.gov.ua/storage/app/media/vishchaosvita/zatverdzeni\%20standarty/2019/05/28/025-muzichne-mistetstvo-bakalavr.pdf

10.Montgomery, A. P., Mousavi, A., Carbonaro, M., Hayward, D. V., \& Dunn, W. (2019). Using learning analytics to explore self-regulated learning in flipped blended learning music teacher education. British Journal of Educational Technology, 50(1), 114-127.

11.Palkki, J., \& Sauerland, W. (2019). Considering Gender Complexity in Music Teacher Education. Journal of Music Teacher Education, 28(3), 72-84. https://doi.org/10.1177/1057083718814582

12.Poblete, C., Leguina, A., Masquiarán, N., \& Carreño, B. (2019). Informal and non formal music experience: power, knowledge and learning in music teacher education in Chile. International Journal of Music Education, 37(2), 272-285.

13.Prokopchuk, V. I. (2020). Yevropeys'kyy dosvid profesiynoyi pidhotovky maybutn'oho vchytelya muzychnoho mystetstva [European experience of professional training of future music teacher]. Riga: Publishing House "Baltija Publishing".

14.Timonen, V., Houmann, A. Sæther, E. H. (2020). The Reinvented Music Teacher-Researcher in the Making: Conducting Educational Development Through Intercultural Collaboration. In Westerlund, H., Karlsen, S., Partti, H. (eds.), Visions for Intercultural Music Teacher Education. Landscapes: the Arts, Aesthetics, and Education, 26. https://doi.org/10.1007/978-3-030-21029-8 7

15.Umrykhina, O. (2019). Suchasni tendentsiyi profesiynoyi pidhotovky fakhivtsiv muzychnoho mystetstva v umovakh yevropeys'koyi osvity [Current Trends of Professional Training of Music Art Specialists in the Conditions of European Education]. Psykholoho-pedahohichni problemy suchasnoyi shkoly, 2, 156-162.

16.Wang, Q. (2019). Professional Training of Music Teacher in the Context of Integration Processes in Education. Issues of BSPU (Series 1), 4, 42-46. 
17.Zamorotska, V. (2019). Dystantsiyne navchannya u formuvanni instrumental'no-vykonavs'koyi kompetentnosti maybutnikh uchyteliv muzyky [Distance Learning in the Formation of Instrumental and Performing Competence of Future Music Teachers]. Naukovyy visnyk Uzhhorods'koho universytetu. Seriya: «Pedahohika. Sotsial'na robota», 2(45), 70-74.

Received: November 12, 2020 Approved: December 15, 2020 